N. Rynkevich

\title{
EMPIRICAL RESEARCH OF DEVELOPMENT FEATURES OF THE ORGANIZATIONAL CULTURE OF CONSTRUCTION ENTERPRISES
}

Problem statement. The problems of development of the organizational culture of enterprises by different types of economic activity are being actualized, taking into account their specificity. This allows for greater flexibility and the ability to respond promptly to changes in the internal and external environment, to strengthen competitive positions in the markets that meet the current conditions of management.

Against this background, the need for theoretical substantiation and the development of practical recommendations to improve the management effectiveness of organizational culture of enterprises in the context of corporate social responsibility have emerged.

Analysis of recent publications on the problem. Over the past decades, foreign and domestic scientists have paid considerable attention to substantiating conceptual provisions and scientific and methodological approaches to improving corporate culture development management. The evolution of development and essence of organizational culture of enterprises from different points of view is investigated, its peculiarities and differences from corporate culture are determined [117]. The mechanisms of managing the organizational culture of enterprises under changing environment are substantiated [18-25]. The impact of organizational culture on the efficiency and level of competitiveness of enterprises was evaluated and the relationship between organizational culture and financial results was proved [26-37]. Various methodological approaches have been proposed, which allow to estimate the level of development of organizational culture [38-44].

The author of this article in the previous researches revealed the modern tendencies of development of the organizational culture of the enterprises according to the results of the expert survey [45]; features, barriers and drivers of digital transformation of organizational culture of enterprises have been investigated [46]; systematic existing scientific approaches to defining the meaning of the term «customer orientation» by classification groups, among which the component of organizational culture, which means the key competence of the enterprise, is highlighted; ability of the company; skill; part of organizational culture, set of beliefs [47]; the structural components of the organizational and economic mechanism for managing the organizational culture of enterprises have been determined [48].

Based on this, despite such close attention to the problem identified by scientists, it remains relevant to conduct scientific research in the field of evaluating the development of organizational culture of construction enterprises using economic and statistical methods. All this largely determined the choice of the topic of this study and its focus.

Setting objectives. The purpose of this article is an empirical research of the organizational culture of construction enterprises, identifying trends in its development in modern conditions and improving the methodical approach to assessing the level of development.

Outline of the main results and their justification. In the last decade there is a tendency of deterioration of labor potential in the construction industry. Thus, the analytical estimation of statistics shows that the number of employed workers in construction enterprises decreased by $40.4 \%$ in $2010-2018$, and their share in the total number of employed workers by all economic activities - by 1.2 percentage points, or from 4.8 to $3.6 \%$. The number of employed workers in construction enterprises decreased by $42.3 \%$ and their share by $1.3 \mathrm{pp}$ or from 5.8 to $4.5 \%$ of the total.

During this period, the number of employees in construction enterprises decreased by $40.3 \%$, and their share in the total number of employees by all types of economic activity - by 1.3 percentage points, or from 5.3 to $4 \%$. The number of employees in construction enterprises decreased by $42.1 \%$ and their share by $1.2 \mathrm{pp}$ or from 5.7 to $4.5 \%$ of the total number (Table 1 ).

Table 1

Dynamics of employed and employees persons at construction enterprises

\begin{tabular}{|c|c|c|c|c|}
\hline \multirow{2}{*}{ Years } & \multicolumn{2}{|c|}{$\begin{array}{c}\text { Number of employed, } \\
\text { thousand people }\end{array}$} & \multicolumn{2}{|c|}{$\begin{array}{c}\text { Number of employees, } \\
\text { thousand people }\end{array}$} \\
\cline { 2 - 5 } & $\begin{array}{c}\text { from } \\
\text { economic } \\
\text { entities }\end{array}$ & $\begin{array}{c}\text { including } \\
\text { at the } \\
\text { enterprises }\end{array}$ & $\begin{array}{c}\text { from } \\
\text { economic } \\
\text { entities }\end{array}$ & $\begin{array}{c}\text { including } \\
\text { at the } \\
\text { enterprises }\end{array}$ \\
\hline 2010 & 524.0 & 472.1 & 477.7 & 462.8 \\
\hline 2013 & 399.6 & 371.7 & 373.2 & 362.1 \\
\hline 2014 & 318.5 & 286.1 & 288.1 & 278.2 \\
\hline 2015 & 282.5 & 248.1 & 247.6 & 239.2 \\
\hline 2016 & 283.9 & 247.0 & 252.8 & 241.7 \\
\hline 2017 & 293.7 & 257.8 & 265.0 & 251.9 \\
\hline 2018 & 312.3 & 272.2 & 285.1 & 268.0 \\
\hline
\end{tabular}

Compiled by: [49, p. 21, 23].

As can be seen from the analysis, the proportion of staff costs on construction enterprises negligible ends to lowering spare. For the years 2010-20188 this figure 
decreased by $0.7 \mathrm{pp}$ or from 3.9 to $3.2 \%$ of the total Ukrainian personnel expenditures. Accordingly, the share of labor costs at construction enterprises decreased by $0.8 \mathrm{pp}$ or from 3.9 to $3.1 \%$ of the volume of labor costs at enterprises for all types of economic activity (Table 2).

\begin{tabular}{|c|c|c|}
\multicolumn{2}{c}{$\begin{array}{c}\text { Table } 2 \\
\text { Dynamics of personnel costs } \\
\text { at construction enterprises }\end{array}$} \\
\hline Years & $\begin{array}{c}\text { Personnel costs - } \\
\text { total, million UAH }\end{array}$ & $\begin{array}{c}\text { Including labor } \\
\text { costs, UAH million }\end{array}$ \\
\hline 2010 & 11024.4 & 8066.5 \\
\hline 2011 & 12498.4 & 9140.3 \\
\hline 2012 & 15197.2 & 11321.4 \\
\hline 2013 & 13681.4 & 10008.6 \\
\hline 2014 & 15182.8 & 11083.7 \\
\hline 2015 & 11628.1 & 8625.4 \\
\hline 2016 & 12612.7 & 10402.2 \\
\hline 2017 & 18167.2 & 14925.3 \\
\hline 2018 & 24325.0 & 19757.3 \\
\hline
\end{tabular}

Compiled by: [49, p. 85].

In order to identify contemporary problems, barriers, features, tendencies and ways of development of organizational culture of construction enterprises in Ukraine, an expert survey was conducted as a method of empirical research. This amounted to $5.2 \%$ of the total number of experts in all economic activities (115 respondents).

It is found that the formation of organizational culture of enterprises is influenced by top managers $(1.7 \%$ of respondents), the owner of the firm $(0.9 \%)$; HR department $(0.9 \%)$ and clients $(0.9 \%)$. Some experts $(0.9 \%)$ said that organizational culture cannot be influenced because it is a process that cannot be managed.

It is proved that organizational culture is usually organized by company management $3.5 \%$ of respondents). A number of experts $(0.9 \%)$ noted that organizational culture was formed spontaneously in their enterprises. And some $(0.9 \%)$ state that they have absolutely no organizational culture.

Most surveyed companies do not impose corporate values and rules (3.5\% of respondents). It was found that the corporate values and slogans stated by the company fully $(3.5 \%$ of respondents) or partially $(0.9 \%)$ coincide with its real values.

Most experts (5.2\%) believe that the organizational culture of companies is effective. Based on the expert survey, key obstacles were identified to change the organizational culture of construction enterprises in the conditions of digitalization of business processes. Among them are: insufficient financial resources (1.7\% of respondents); underdevelopment of IT infrastructure $(0.9 \%)$; imperfection of the organizational structure $(0.9 \%)$; lack of clear vision and support of the management $(0.9 \%)$; low level of employee involvement $(0.9 \%)$.
It was found that the values and principles, on which the organizational culture of the surveyed enterprises is formed, largely or partially, correspond to the personal values and principles of employees $(1.7 \%$ of respondents each).

Experts say that organizational culture affects the financial performance of enterprises (3.5\% of respondents). Successful organizational culture of construction companies can reduce costs and costs $(2.6 \%)$; increase the level of profitability $(1.7 \%)$; to increase sales volumes by improving the quality of logistics services $(0.9 \%)$.

Based on the expert survey, it was found that the surveyed enterprises required complete $(1.7 \%$ of respondents) or partial (3.5\%) transformation of organizational culture. According to the respondents, the modernization of organizational culture should consist of upgrading of employees $(3.5 \%)$ and introduction of digital technologies in order to optimize business processes $(1.7 \%)$. However, construction companies do not point to the feasibility of transforming the relationship management system with consumers. This is mostly the case with companies in services, education and science, food industry, wholesale and retail trade.

The formation and development of the organizational culture of enterprises in the field of construction are significantly influenced by endogenous factors, which include the following: organization management (scientific and technical and innovative activities, production, personnel management, marketing and logistics, financial status, communication policy, planning and strategizing); employees of the organization (loyalty to personnel policy, personnel management, mission of the organization, work activity; observance of interests of the organization, confidentiality of information, value orientation). The above factors require the use of certain techniques and tools that can succeed in transforming the organizational culture of enterprises.

Therefore the author during the expert survey was focus on internal factors that influence the development of organizational culture of surveyed companies (Table 3).

It is established that, as a rule, the key companies are not formed on the construction enterprises and the strategic direction of the companies' activity is not defined. Most experts pointed to a lack of consistent and predictable approach to doing business and a clear overlap of goals across all hierarchical levels of the company (Table 4).

In construction companies, insufficient attention is paid to organizational training. For the most part, innovative ideas are not supported, employees are not encouraged to be creative and constantly improve their skills and knowledge (Table 5). It does not meet the modern requirements of the functioning of enterprises. This is especially true in the context of the intensive use of digital technologies, when the personnel must have digital competencies and the organizational culture of enterprises is transformed. 
Expert assessment of the influence of endogenous factors on development organizational culture of construction enterprises

\begin{tabular}{|c|c|}
\hline Assertion & $\begin{array}{l}\% \text { to the respon- } \\
\text { dents }\end{array}$ \\
\hline \multicolumn{2}{|l|}{ 1. The life of an organization should be guided by: } \\
\hline constant coordination and discussion of all employees of the organization & 66.7 \\
\hline teamwork based on a common idea & 33.3 \\
\hline \multicolumn{2}{|l|}{ 2. The real leader (leader) must first of all: } \\
\hline possess various resources (image, money, connections, etc.) and enjoy recognition from subordinates & 33.3 \\
\hline to initiate the process of creativity & 66.7 \\
\hline \multicolumn{2}{|l|}{ 3. Everyday work should: } \\
\hline to constantly improve & 66.7 \\
\hline performed and changed by each employee in their own way, based on the ultimate goal & 33.3 \\
\hline \multicolumn{2}{|l|}{ 4. Desires and interests of individual employees: } \\
\hline individual and should be considered by the organization if it wants to achieve its goals & 100.0 \\
\hline \multicolumn{2}{|l|}{ 5. The main task of management: } \\
\hline $\begin{array}{l}\text { clearly structure business processes, create instructions, regulations, regulations and work with subordinates } \\
\text { with their help }\end{array}$ & 33.3 \\
\hline $\begin{array}{l}\text { to set the general context of team movement and interaction, to provide employees with opportunities for } \\
\text { development }\end{array}$ & 66.7 \\
\hline \multicolumn{2}{|l|}{6. Discrepancies and conflicts between employees are: } \\
\hline threat to the stability of the organization, which interferes with the work & 33.3 \\
\hline productive expression of individual opinions and differences of opinion & 66.7 \\
\hline \multicolumn{2}{|l|}{ 7. Communication between employees should be based on: } \\
\hline open, comprehensive discussion of work issues & 100.0 \\
\hline \multicolumn{2}{|l|}{ 8. Working information and data: } \\
\hline it is a common knowledge that does not need to be brought out & 33.3 \\
\hline must be controlled and restricted & 66.7 \\
\hline \multicolumn{2}{|l|}{ 9. Decisions in the organization should be made on the basis of: } \\
\hline roundtable discussion that allows you to see the problem from different angles & 66.7 \\
\hline potential benefits (profits) and risks & 33.3 \\
\hline \multicolumn{2}{|l|}{ 10. It is preferable to do something: } \\
\hline focusing on the benefits to yourself and the organization & 33.3 \\
\hline in line with the overall goals, objectives, and traditions of the organization & 33.3 \\
\hline following the rules and instructions & 33.4 \\
\hline \multicolumn{2}{|l|}{ 11. The working environment should be: } \\
\hline harmonious, comfortable, and should like the staff & 100.0 \\
\hline \multicolumn{2}{|l|}{ 12. The basic principle of the organization should be: } \\
\hline «We are one family» & 33.3 \\
\hline there are no limits to perfection & 66.7 \\
\hline
\end{tabular}

Prepared by the author according to the results of the survey.

Note: 114 experts in various economic fields were interviewed, including $3(2.6 \%)$ in construction. The share of respondents is calculated to the total number of experts of the respective type of economic activity.

\section{Answers to the question}

«What do you think are the goals and principles of the company?»

\begin{tabular}{|l|c|c|c|}
\hline \multicolumn{1}{|c|}{ Assertion } & \multicolumn{2}{c|}{ Responses, \% of experts } \\
\cline { 2 - 4 } & So & No & Part \\
\hline There is a long-term purpose and direction of activity & - & 50.0 & 50.0 \\
\hline Our strategy causes other organizations to change their methods of competition & 16.7 & 50.0 & 33.3 \\
\hline There is a clear mission that gives meaning and direction to our work & - & 50.0 & 50.0 \\
\hline There is a clear strategy for the future & - & 66.7 & 33.3 \\
\hline Our strategic direction to employees is unclear & 33.3 & 16.7 & 50.0 \\
\hline Short-term thinking threatens long-term vision & 50.0 & 16.7 & 33.3 \\
\hline Our approach to doing business is consistent and predictable & 16.7 & 33.3 & 50.0 \\
\hline Employees from different departments share a common perspective & - & 16.7 & 83.3 \\
\hline It is easy to coordinate projects between different departments of the company & 16.7 & 50.0 & 33.3 \\
\hline $\begin{array}{l}\text { Working with someone from another company department is like working with } \\
\text { someone from another company }\end{array}$ & 16.6 & 16.7 & 66.7 \\
\hline There is a clear overlap of goals at all levels of the company & - & 66.7 & 33.3 \\
\hline
\end{tabular}

Prepared by the author according to the results of the survey.

Note: the proportion is calculated to the total number of experts of the respective economic activity. 
Answers to questions regarding the organization of training while working at the company

\begin{tabular}{|l|c|c|c|}
\hline \multicolumn{1}{|c|}{ Assertion } & \multicolumn{3}{c|}{ Responses, $\%$ of experts } \\
\cline { 2 - 4 } & So & No & Part \\
\hline We see error as an opportunity to learn and improve & 16.7 & - & 83.3 \\
\hline Innovation and risk are encouraged and rewarded & 16.7 & 66.7 & 16.6 \\
\hline Many things are «lost in the system» & 16.7 & 50.0 & 33.3 \\
\hline Learning is an important goal of our daily activities & 16.7 & 50.0 & 33.3 \\
\hline Employees are encouraged to be creative & - & 66.7 & 33.3 \\
\hline We can introduce new ideas & 16.6 & 16.7 & 66.7 \\
\hline New ideas are constantly being evaluated and improved & - & 50.0 & 50.0 \\
\hline It is ready to support the development of new ideas & 33.3 & 50.0 & 16.7 \\
\hline Innovation is a «painful» issue of our business activity & 33.4 & 33.3 & 33.3 \\
\hline
\end{tabular}

Prepared by the author according to the results of the survey.

Note: the proportion is calculated to the total number of experts of the respective economic activity.

Based on empirical research, it has been found that construction companies do not implement corporate social responsibility mechanisms in the context of sustainable development. Most respondents noted that companies did not invest in the transformation of organiza- tional culture, did not implement the concept of sustainable development, and did not develop corporate codes. Organizational culture does not meet the goals and principles of sustainable development (Table 6). Consequently, construction managers tend to aim at reducing costs and increasing profitability.

Table 6

\section{Expert evaluation of organizational culture construction companies in the corporate social responsibility system in the context of sustainable development}

\begin{tabular}{|c|c|c|c|}
\hline \multirow{2}{*}{ Assertion } & \multicolumn{3}{|c|}{ Responses, $\%$ of experts } \\
\hline & So & No & Part \\
\hline The company is investing in the modernization of its organizational culture & 16.6 & 66.7 & 16.7 \\
\hline $\begin{array}{l}\text { The company implements special programs } \\
\text { on the transformation of organizational culture within the Corporate Code }\end{array}$ & - & 83.3 & 16.7 \\
\hline $\begin{array}{l}\text { The company does not pay due attention to the modernization of organizational cul- } \\
\text { ture, which leads to deterioration of the financial condition of the company }\end{array}$ & 33.4 & 33.3 & 33.3 \\
\hline $\begin{array}{l}\text { The company implements the concept of sustainable development, one of the } \\
\text { elements of which is organizational culture }\end{array}$ & - & 66.7 & 33.3 \\
\hline $\begin{array}{l}\text { Issues of organizational culture development are clearly presented in the strategic } \\
\text { planning process of the company }\end{array}$ & - & 83.3 & 16.7 \\
\hline $\begin{array}{l}\text { Issues of organizational culture development are presented in the company's mission } \\
\text { or basic principles of doing business }\end{array}$ & - & 66.7 & 33.3 \\
\hline $\begin{array}{l}\text { When organizational culture development issues are clearly presented in the strate- } \\
\text { gic planning process of the company, the top management team makes cautious far- } \\
\text { sighted decisions }\end{array}$ & 16.6 & 33.3 & 50.0 \\
\hline $\begin{array}{l}\text { The staff influences the process of strategic management of organizational culture } \\
\text { development }\end{array}$ & - & 83.3 & 16.7 \\
\hline Organizational culture is an important component of corporate responsibility & 16.7 & 50.0 & 33.3 \\
\hline The company has a Corporate Code, a key element of which is organizational culture & - & 66.7 & 33.3 \\
\hline $\begin{array}{l}\text { Organizational culture is consistent with the goals and principles of sustainable de- } \\
\text { velopment }\end{array}$ & - & 83.3 & 16.7 \\
\hline
\end{tabular}

Prepared by the author according to the results of the survey.

Note: the proportion is calculated to the total number of experts of the respective economic activity.

An important element of the organizational culture of construction companies is the channels of internal communication. Experts noted that most often they use e-mail, the corporate website of the company, and sometimes the personal folder of the manager; corporate forum, chat; internal communication tools (video conferences, seminars, trainings); personal blogs, chats. The majority of respondents do not use personal blogs or chats at all (Table 7).
Based on the expert survey, the level of development of organizational culture of construction enterprises was estimated. For this purpose, indicators reflecting the characteristics of organizational culture have been identified and calculated. Thus, changes in the company, consumer orientation and organizational training characterize the adaptability of the organizational culture; strategic planning, goal setting and vision - mission; coordination, agreement and values - in- 
teraction; ability development, teamwork, responsibility and authority - involvement. In the Table 8 presents the data of calculation of the level of development of organizational culture of the surveyed enterprises.

Definition of internal communication channels and the frequency of their use in construction enterprises

\begin{tabular}{|l|c|c|c|}
\hline \multicolumn{1}{|c|}{ Channels } & \multicolumn{3}{c|}{$\begin{array}{c}\text { Intensity of use, } \\
\text { \% of experts }\end{array}$} \\
\cline { 2 - 4 } & Often & Sometimes & Never \\
\hline Corporate site of the company & 60 & 20 & 20 \\
\hline Email & 80 & 20 & - \\
\hline Corporate forum, chat, email & 40 & 60 & - \\
\hline Personal blogs and chats & - & 40 & 60 \\
\hline $\begin{array}{l}\text { Internal communication tools (reception hours of executives, information } \\
\text { meetings, conferences, roundtables, meetings, conference calls, videoconfer- } \\
\text { ences, trainings, training programs, personal communication of employees, } \\
\text { corporate holidays) }\end{array}$ & 20 & & \\
\hline Manager personal folder (for transferring information) & 60 & 20 \\
\hline
\end{tabular}

Prepared by the author according to the results of the survey.

Note: 130 experts in various economic activities were interviewed, including 5 in the field of construction.

Calculation of characteristics of organizational culture of construction enterprises

\begin{tabular}{|c|c|c|c|c|}
\hline Features & \multicolumn{3}{|c|}{ Name and value of indicators, points } & $\begin{array}{l}\text { Characteristic } \\
\text { values, points }\end{array}$ \\
\hline \multirow{2}{*}{ Adaptability } & Changes in the company & Consumer-oriented & Organizational training & \multirow[b]{2}{*}{0.33} \\
\hline & 0.19 & 0.34 & 0.47 & \\
\hline \multirow{2}{*}{ Mission } & Strategic planning & Goal setting & Vision & \multirow{2}{*}{0.33} \\
\hline & 0.37 & 0.38 & 0.25 & \\
\hline \multirow{2}{*}{ Interaction } & Coordination & Consistency & Values & \multirow{2}{*}{0.33} \\
\hline & 0.50 & 0.27 & 0.23 & \\
\hline \multirow{2}{*}{ Engagement } & Capability development & Teamwork & Responsibility and authority & \multirow{2}{*}{0.33} \\
\hline & 0.20 & 0.43 & 0.37 & \\
\hline In general & \multicolumn{3}{|c|}{0.33} & \\
\hline
\end{tabular}

Compiled and calculated by the author on the results of the survey.

Note: 127 experts from various economic activities were interviewed, including 6 experts in the field of construction.

Calculations showed that the assessment of organizational culture surveyed is 0.33 points. According to the scale (Table 9) the level of development of organizational culture of enterprises in the field of construction is low, because it is in the range of $0.26-0.5$ points.

Table 9

The scale of assessment of the level of development of organizational culture

\begin{tabular}{|c|c|}
\hline $\begin{array}{c}\text { Assessment of organiza- } \\
\text { tional culture, points }\end{array}$ & $\begin{array}{c}\text { The level of development } \\
\text { of organizational culture }\end{array}$ \\
\hline $0-0.25$ & Very low \\
\hline $0.26-0.5$ & Low \\
\hline $0.51-0.75$ & Average \\
\hline $0.76-1.0$ & High \\
\hline
\end{tabular}

Compiled by the author on expert estimates.

To assess the level of development of organizational culture of construction enterprises, the technique of D. Denison was used. The survey includes 60 questions, organized into 4 groups: adaptability, mission, consistency and engagement. When filling out the questionnaire, 60 statements are evaluated on a five-point scale (from 1 to 5 points), after which the respondents' answers are translated into the average value of the evaluation of organizational culture characteristics. The next step is to calculate the arithmetic average of the scores on the survey items, for five questions for each index, as well as the average of the indices for the characteristics of the organizational culture. The average value of indicators of characteristics of culture is calculated. The average value of organizational culture determines the level of its development as a whole.

The calculations show that the organizational culture of construction companies is 0.69 (adaptability is 0.68 ; mission is 0.70 ; consistency is 0.72 ; engagement is 0.67 ), it is within $0.51-0.75$. This means that the level of development of the organizational culture of the surveyed enterprises is average (Table 10). 
Calculation of characteristics of organizational culture of construction enterprises

\begin{tabular}{|c|c|c|}
\hline Indicators & Assertion & Rating \\
\hline 1 & 2 & 3 \\
\hline \multicolumn{3}{|c|}{ The ability to adapt } \\
\hline \multirow{5}{*}{$\begin{array}{l}\text { The ability } \\
\text { to change } \\
\text { (0.65) }\end{array}$} & The organization is very flexible and easy to change under the influence of external factors & 0.50 \\
\hline & $\begin{array}{l}\text { An organization aware of what is happening to competitors and trying to respond to } \\
\text { changes in the external business environment }\end{array}$ & 0.75 \\
\hline & The organization constantly uses qualitatively new ways of doing work & 0.75 \\
\hline & Changes in organization are rarely met with employee resistance & 0.50 \\
\hline & $\begin{array}{l}\text { Various departments within this organization often collaborate to make the necessary } \\
\text { changes }\end{array}$ & 0.75 \\
\hline \multirow{5}{*}{$\begin{array}{c}\text { Attention } \\
\text { to customers } \\
(0.75)\end{array}$} & Customer comments and recommendations often lead to changes in the organization & 0.75 \\
\hline & The customer's opinion directly influences our decisions & 0.75 \\
\hline & $\begin{array}{l}\text { All employees of the organization have a deep understanding of the wishes and needs } \\
\text { of the client }\end{array}$ & 0.75 \\
\hline & We encourage direct contact with members of the organization & 0.75 \\
\hline & The interests of the end consumer are never ignored in our decisions & 0.75 \\
\hline \multirow{5}{*}{$\begin{array}{c}\text { Organizational Train- } \\
\text { ing } \\
(0.65)\end{array}$} & The organization encourages and rewards innovation and risk-taking & 0.75 \\
\hline & We see failure as an opportunity for learning and improvement & 0.50 \\
\hline & There are no major omissions in the organization & 0.50 \\
\hline & Learning is an important goal of daily work & 0.75 \\
\hline & We try to be sure that «the right hand knows what the left does» & 0.75 \\
\hline \multicolumn{3}{|c|}{ Mission } \\
\hline \multirow{5}{*}{$\begin{array}{c}\text { Strategic direction and } \\
\text { intentions } \\
(0.70)\end{array}$} & The organization has a clear mission that gives meaning and direction to our work & 0.75 \\
\hline & The organization has a long-term goal and direction & 0.75 \\
\hline & The employee understood the strategic direction of the organization & 0.75 \\
\hline & The organization has a clear strategy for the future & 0.75 \\
\hline & The organization's strategy forces other firms to change their competitive strategies & 0.50 \\
\hline \multirow{5}{*}{$\begin{array}{l}\text { Goals } \\
\text { and Objectives } \\
(0.75)\end{array}$} & $\begin{array}{l}\text { There is complete agreement about the goals of the organization between employees } \\
\text { and executives }\end{array}$ & 0.75 \\
\hline & The organization's leaders set far-reaching but realistic goals & 0.75 \\
\hline & $\begin{array}{l}\text { Leaders of the organization formally, publicly and openly speak about the goals we are } \\
\text { trying to achieve }\end{array}$ & 0.75 \\
\hline & We are constantly monitoring our progress against our stated goals & 0.75 \\
\hline & Employees at the organization understand what needs to be done to succeed in the long run & 0.75 \\
\hline \multirow{5}{*}{$\begin{array}{l}\text { Vision } \\
(0.65)\end{array}$} & The organization has a vision for the future & 0.50 \\
\hline & Leaders in the organization are forward-looking & 0.75 \\
\hline & Short-term goals rarely conflict with the long-term orientation of the organization & 0.75 \\
\hline & Our vision of the future inspires and motivates our employees & 0.50 \\
\hline & We are able to accomplish short-term tasks without compromising our long-term prospects & 0.75 \\
\hline \multirow{6}{*}{$\begin{array}{c}\text { Coordination } \\
\text { and integration } \\
(0.65)\end{array}$} & \multirow{2}{*}{$\begin{array}{c}\text { Consistency } \\
\text { Our approach to doing business is very consistent and predi }\end{array}$} & \\
\hline & & 0.75 \\
\hline & There is a clear alignment of goals across the organization & 0.75 \\
\hline & Employees from different organizational units share common perspectives & 0.75 \\
\hline & It is easy to coordinate projects in different functional units of the organization & 0.50 \\
\hline & $\begin{array}{l}\text { It is much easier to work with someone in another organization than it is to work with } \\
\text { someone from another company }\end{array}$ & 0.50 \\
\hline \multirow{5}{*}{$\begin{array}{l}\text { Consensus } \\
\text { power } \\
(0.75)\end{array}$} & $\begin{array}{l}\text { When there are differences, we work hard to reach a mutually beneficial solution for all } \\
\text { parties to the conflict }\end{array}$ & 0.75 \\
\hline & The firm has a strong organizational culture & 0.75 \\
\hline & $\begin{array}{l}\text { There is a clear agreement on the right and wrong approaches to performing work in the } \\
\text { organization }\end{array}$ & 0.75 \\
\hline & It is easy for us to reach agreement even on difficult issues & 0.75 \\
\hline & We rarely find it difficult to reach agreement on key issues & 0.75 \\
\hline \multirow{5}{*}{$\begin{array}{l}\text { Engagement } \\
\text { in value } \\
(0.75)\end{array}$} & The company has a clear and consistent set of values that determines how it does business & 0.75 \\
\hline & This company has a distinctive management style and a clear set of management methods & 0.75 \\
\hline & Executives show an example of reinforcing words with cases & 0.75 \\
\hline & There is an organization code of ethics that defines employee behavior & 0.75 \\
\hline & Ignoring the core values of the organization can lead to trouble & 0.75 \\
\hline
\end{tabular}


N. Rynkevich

\begin{tabular}{|c|c|c|}
\hline \multicolumn{3}{|c|}{ Ending of table 10} \\
\hline 1 & 2 & 3 \\
\hline \multicolumn{3}{|c|}{ Engagement } \\
\hline \multirow{5}{*}{$\begin{array}{l}\text { Authorization } \\
\quad(0.65)\end{array}$} & Most employees in the organization are actively involved in their work & 0.75 \\
\hline & $\begin{array}{l}\text { Organizational decisions are usually made at the level where the best information is avail- } \\
\text { able }\end{array}$ & 0.75 \\
\hline & $\begin{array}{l}\text { The information is widely disseminated in an organization where anyone can access the } \\
\text { information they need }\end{array}$ & 0.75 \\
\hline & $\begin{array}{l}\text { Each employee believes that he can have a positive impact on the work of the entire organ- } \\
\text { ization }\end{array}$ & 0.50 \\
\hline & $\begin{array}{l}\text { Business planning in the organization is ongoing and in one way or another attracts every } \\
\text { employee }\end{array}$ & 0.50 \\
\hline \multirow{5}{*}{$\begin{array}{c}\text { Development } \\
\text { opportunities } \\
(0.70)\end{array}$} & The organization delegates power to allow employees to act independently & 0.75 \\
\hline & $\begin{array}{l}\text { People's abilities in an organization are seen as an important source of competitive ad- } \\
\text { vantage }\end{array}$ & 0.75 \\
\hline & The organization continuously invests in the training of its employees & 0.50 \\
\hline & The level of human capacity of the organization is constantly increasing & 0.75 \\
\hline & Problems rarely arise in an organization, so employees have the skills they need to work & 0.75 \\
\hline \multirow{5}{*}{$\begin{array}{l}\text { Teamwork } \\
\text { orientation } \\
(0.65)\end{array}$} & $\begin{array}{l}\text { Co-operation and collaboration of employees with different functional roles in the organi- } \\
\text { zation are actively encouraged }\end{array}$ & 0.50 \\
\hline & Working in an organization means being part of a team & 0.50 \\
\hline & $\begin{array}{l}\text { Work is organized in the company so that every second employee was able to see the link } \\
\text { between their activities and goals of the organization }\end{array}$ & 0.75 \\
\hline & Teams - primary «building blocks» of the organization & 0.75 \\
\hline & Organizations rely more on horizontal control and coordination than on a hierarchy position & 0.75 \\
\hline
\end{tabular}

Compiled and calculated by the author on the results of the survey.

Due to the fact that completing the Denison's survey and assessing the level of organizational culture is time consuming, the author has proposed an improved methodology. The process of developing an integral methodology for quantitative assessment of organizational culture consists of the following stages: preparation of a questionnaire of 24 statements regarding the characteristics of organizational culture of enterprises; development of methods of analysis and evaluation of organizational culture.

The questionnaire consists of 24 statements based on the techniques of Denison and Hofstede. As a result, a new questionnaire is formed with 24 statements, assessments of which determine the organizational culture profile.

The assessment methodology is quantitative and includes procedures for collecting and analyzing data on the organizational culture of the enterprise. The procedure of organizational culture research consists of the following stages: filling in the questionnaires by experts; collecting and processing of received data; analysis and evaluation of the organizational culture development of the enterprise. The analysis and evaluation of organizational culture is carried out by calculating the obtained indicators with the following steps:

1. Translating respondents' answers from a fivepoint rating scale to the average of the evaluation of organizational culture characteristics (Table 11).

Table 11

Transfer of points in the answers of the respondents

\begin{tabular}{|l|c|c|c|c|c|}
\hline Answer values (points) & 1 & 2 & 3 & 4 & 5 \\
\hline Evaluation of answers & 0 & 0.25 & 0.5 & 0.75 & 1 \\
\hline
\end{tabular}

Compiled by the author.
2. The average arithmetic estimation of indicators on the items of the questionnaire (total 24) is calculated.

3. The arithmetic mean of two questions for each indicator is calculated (12 in total).

4. The average value of indicators on the characteristics of culture (total 4) is calculated.

5 . The average value of indicators of cultural characteristics is calculated. The average value of organizational culture determines the level of its development as a whole.

Calculations on the example of construction companies showed that the Alpha Cronbach's ratio is 0.999 . The coefficient of variation is $16.4 \%$. In this regard, it is possible to take the average values for analyzing the organizational culture of enterprises (Tables 12, 13).

Table 12

The arithmetic average of indicators
for the points of the questionnaire
\begin{tabular}{|c|c|c|c|}
\hline $\begin{array}{c}\text { Questionnaire } \\
\text { points }\end{array}$ & Rating & $\begin{array}{c}\text { Questionnaire } \\
\text { points }\end{array}$ & Rating \\
\hline 1 & 0.464 & 13 & 0.607 \\
\hline 2 & 0.607 & 14 & 0.607 \\
\hline 3 & 0.679 & 15 & 0.679 \\
\hline 4 & 0.750 & 16 & 0.779 \\
\hline 5 & 0.679 & 17 & 0.714 \\
\hline 6 & 0.464 & 18 & 0.750 \\
\hline 7 & 0.786 & 19 & 0.786 \\
\hline 8 & 0.607 & 20 & 0.607 \\
\hline 9 & 0.786 & 21 & 0.821 \\
\hline 10 & 0.643 & 22 & 0.536 \\
\hline 11 & 0.750 & 23 & 0.929 \\
\hline 12 & 0.571 & 24 & 0.750 \\
\hline
\end{tabular}

Designed and compiled by the author. 


\begin{tabular}{|c|c|}
\hline \multicolumn{2}{|c|}{$\begin{array}{c}\text { Assessment of organizational culture } \\
\text { characteristics of construction enterprises }\end{array}$} \\
\hline $\begin{array}{l}\text { Organizational Culture Characteristics / } \\
\text { Indicators }\end{array}$ & $\begin{array}{l}\text { Average } \\
\text { Values }\end{array}$ \\
\hline Adaptability & 0.608 \\
\hline The capacity for organizational change & 0.536 \\
\hline Focusing on consumers & 0.715 \\
\hline Organizational training & 0.572 \\
\hline Mission & 0.691 \\
\hline Strategic direction and intentions & 0.697 \\
\hline Objectives and perspectives & 0.715 \\
\hline Vision & 0.661 \\
\hline Consistency (consistency) & 0.689 \\
\hline Key values & 0.732 \\
\hline The ability to consensus & 0.729 \\
\hline Coordination and integration & 0.607 \\
\hline Engagement & 0.739 \\
\hline Delegation of authority & 0.786 \\
\hline Orientation to teamwork & 0.840 \\
\hline Capability development & 0.679 \\
\hline Overall score & 0.682 \\
\hline
\end{tabular}

Designed and compiled by the author.

Thus, the calculations of the integral index of organizational culture showed that construction enterprises have an average level of its development, since the values are in the range of 0.5 to 0.75 .

Conclusions. The results of the study allow us to draw the following conclusions. Enterprises in the construction sector have a fairly clear idea of their purpose and direction (the value of the indicator «Strategic direction and intentions» -0.697$)$. The mission statement, understood by the management, is understood by all employees and gives their actions purposefulness (Goal and perspective indicator -0.715 ).

Companies have a sufficient level of employee dedication, their own approach to doing business (Coordination and Integration indicator -0.607 ) and a clear set of key values (Key Value Indicator - 0.732).

Enterprises in the construction industry have a sufficient understanding of their customers' needs and needs (consumer focus indicator is 0.715 , but they are not well adjusted to organizational changes and are not adaptable to changes in the environment (Change ability indicator 0.536; Organizational learning indicator 0.572).

Employees of construction companies have a high level of involvement: they are dedicated to their work (the indicator «Development opportunities»-0.679; the indicator «Orientation to work in a team» -0.840 ).

It should be noted that in modern conditions, construction companies should focus on flexible development and internal focus.

Prospects for further research in this area are to develop a marketing strategy for managing the organizational culture of enterprises of different types of economic activity, taking into account their specificity.
Literature
1. Корпоративна культура / під заг. ред. Г.Л. Хаєта. Київ: Центр навчальної літератури, 2003. 403 с. 2. Элвессон М. Организационная культура / пер. с англ. Харьков: Изд-во Гуманитарный Центр, 2005. 460 с. 3. Шейн Э. Организационная культура и лидерство: учебник. 3-е изд. / пер. с англ. под ред. Т.Ю. Ковалевой. СПб.: Питер, 2007. 336 с. 4. Мороз О.В., Карачина Н.П., Халімон Т.М. Корпоративне управління на підприємствах України: постприватизаційний етап еволюції: монографія. Вінниця: УНІВЕРСУМ Вінниця, 2007. 180 с. 5. Армстронг М. Практика управления человеческими ресурсами. 10-е изд. / пер. с англ. под ред. С.К. Мордовина. СПб.: Питер, 2009. 848 с. 6. Бала О.І., Мукан О.В., Бала Р.Д. Принципи корпоративної культури підприємств: сутність та види. Вісник НУ «Львівська політехніка». 2010. Вип. № 682. C. 11-15. URL: http://ena.lp.edu.ua:8080/bitstream/ ntb/7852/1/02.pdf. 7. Захарчин Г.М., Любомудрова Н.П., Винничук Р.О., Смолінська Н.В. Корпоративна культура: навч. посібник / під заг. ред. Г.М. Захарчина. Львів: НУ «Львівська політехніка», 2011. 317 с. 8. Тимцуник В.І., Гайдай Ю.В. Роль організаційної культури в діяльності підприємств торгівлі. Державне уnравління: удосконалення та розвиток. 2011. № 3. URL: http:www.dy.nayka.com.ua/?op=1\&z=267. 9. Лагутіна Т. Організаційна культура у проблемному інституційному середовищі. Вісник КНТЕУ. 2012. № 3. С. 123131. 10. Ліфінцев Д. Роль організаційної культури у довгостроковому розвитку організацій. Стратегія економічного розвитку Украӥни. 2014. № 35. С. 107114. 11. Карамушка Л.М., Креденцер О.В., Терешенко К.В. та ін. Психологічні детермінанти розвитку організаційної культури: монографія / за ред. Л.М. Карамушки. Київ: Педагогічна думка, 2015. 288 с. 12. Озірська Н.В. Концептуальні відмінності та точка перетину організаційної та корпоративної культури. Науковий вісник Херсонського державного університету. Сер.: Економічні науки. 2015. Вип. 13. Ч. 3. С. 9194. 13. Дорошук Г.А. Управління організаційним розвитком: теоретичні та концептуальні основи: монографія / під ред. С.К. Харічкова. Одеса: Бондаренко М.О., 2016. 196 с. 14. Харун О.А., Стецюк О.В. Сутнісні характеристики корпоративної культури підприємств. Економіка і суспільство. 2017. Вип. № 13. С. 139-144. 15. Андросова О.Ф. Історичні аспекти виникнення поняття «корпоративна культура»: сутність, елементи, властивості, типи. Інтеграція освіти, науки і бізнесу: монографія. Запоріжжя: Запорізький нац. ун-т, 2017. Т. 5. С. 94-101. 16. Фокіна-Мезенцева К.В. Мотиваційні основи корпоративної культури в системі менеджменту якості підприємства: теорія, методологія, практика: монографія. Херсон: Видавничий дім «Гельветика», 2018. 300 с. 17. Отенко І.П., Чепелюк М.І. Корпоративна культура: міжнародний та трансформаційний аспекти: монографія. Харків: ХНЕУ ім. С. Кузнеця, 2018. 243 с. 18. Кирхлер Э., Шрот А. Принятие решений в организациях. Психология труда и организационная психология / Пер. с нем. Харьков: Изд-во Гуманитарный Центр, 2004. 160 с. 19. Кузнецова С.А., Кузнецов А.А. Формування корпоративної культури в 
залежності від специфіки підприємства. Проблеми економіки. 2011. № 4. С. 91-94. 20. Діденко Н.В. Формування механізму організаційної культури. Бізнес Iнформ. 2012. № 6. С. 206-207. 21. Кузнецов А.А. Принципи управління корпоративною культурою підприємства в нестабільній економіці. Бізнес Інформ. 2013. № 7. С. 352-356. 22. Волянська-Савчук Л.В. Трансформація корпоративної культури машинобудівних підприємств. Економіка: реалї часу. 2014. № 6(16). С. 50-56. 23. Поторочин С.О. Управління організаційною культурою на промислових підприємствах. Економіка: реалї̈ часу. 2014. № 3(13). С. 57-63. 24. Дергачова В.В., Федірко Г.А. Особливості формування корпоративної культури на підприємствах України. Економічний вісник НТУУ «КПI». 2018. № 15. С. 1-8. doi: https://doi.org/10.20535/2307-5651.15.2018.135694. 25. Телішевська Л.І., Успаленко В.І. Тенденції розвитку системи управління персоналом на підприємстві. Економічний вісник Донбасу. 2019. № 2(56). C. 187-197. doi: 10.12958/1817-3772-2019-2(56)-187197. 26. Denison D.R. Bringing corporate culture to the bottom line. Organizational Dynamics. 1984. Vol. 13 (2). P. 4-22. 27. Irani Z., Beskase A., Love P.E.D. Total quality management and corporate culture: constructs of organizational excellence. The International Journal of Technological Innovation, Entrepreneurship and Technology Management - Technovation. 2004. Vol. 24. P. 643650. 28. Kwan P., Walker A. Validating the competing values model as a representation of organizational culture through inter-institutional comparisons. Organizational Analysis. 2004. Vol. 12. No 1. P. 21-37. 29. Millington M.J., Schultz J.C. The Challenge of Organization Culture in Quality Assurance Implementation. Journal of Rehabilitation Administration. 2009. Vol. 33. P. 121-130. 30. Харчишина О.В. Організаційна культура: теоретичні засади та взаємозв'язок із конкурентоспроможністю підприємства. Забезпечення соціально-економічного розвитку господарюючих систем в умовах транзитивної економіки: монографія / за заг. ред. В.К. Данилка, Г.М. Тарасюк. Житомир: Вид-во ЖДТУ, 2010. C. 182-202. 31. Cameron K.S., Quinn R.E. Diagnosing and Changing Organizational Culture: Based on the Competing Values Framework. 3rd ed. New Jersey: John Wiley \& Sons, 2011. 288 p. 32. Roldan J.L., LealRodríguez A.L., Leal A.G. The influence of organizational culture on the Total Quality Management Programme performance. Investigaciones Europeas de Dirección y Economía de la Empresa. 2012. Vol. 18. P. 183-189. 33. Кравченко В.О., Никифоренко В.Г. Оцінка впливу організаційної культури на ефективність та конкурентоспроможність підприємства. Бізнес Інформ. 2012. № 10. С. 260-263. 34. Знак К.О. Порівняльний аналіз методичних підходів до діагностування корпоративної культури та перспективи їх використання на підприємствах машинобудівної галузі. Бізнес Інформ. 2012. № 11. С. 270-272. 35. Овчаренко М.I., Червякова С.В. Методичне забезпечення оцінки стану корпоративної культури підприємства. Маркетинг і менеджмент інноваџій. 2013. № 2. С. 130-141. 36. Lapina I., Kairisa I., Aramina D. Role of Organizational Culture in the Quality Management of University. 20th International Scientific Conference Economic and
Management - 2015 (ICEM - 2015). Procedia - Social and Behavioral Sciences. 2015. Vol. 213. P. 770-774. doi: 10.1016/j.sbspro.2015.11.472. 37. Жежер К.Л. Основні підходи та методики діагностики корпоративної культури сучасного підприємства. Молодий вчений. 2015. № 11(26). C. 61-64. 38. Denison D.R. Corporate culture and organizational effectiveness. New York: John Wiley \& Sons, 1990. 267 p. 39. Hofstede G. Dimensionalizing Cultures: The Hofstede Model in Context. Online Readingsin Psycology and Culture. 2011. Vol. 2 (1). P. 17. 40. Денисон Д., Хойшберг Р., Лэйн Н., Лиф К. Изменение корпоративной культуры в организациях / Пер. с англ. СПб.: Питер, 2013. 192 с. 41. Зеркаль А.В. Моделювання розвитку корпоративної культури на машинобудівних підприємствах. Ефективна економіка. 2012. № 9. URL: http:www.economy.nayka.com.ua/?op = $1 \& z=1389.42$. Кузнецов А.А. Моделювання полікритеріальної оцінки стану управління корпоративною культурою машинобудівних підприємств. Інвестищіï: практика та досвід. 2013. № 19. С. 88-91. 43. Войнаренко М.П., Волянська-Савчук Л.В. Застосування експертних методів дослідження для оцінки рівня корпоративної культури на підприємствах машинобудування. Вісник Хмельницького національного університету. Сер.: Економічні науки. 2016. № 5. Т. 1. С. 298300. 44. Чанг То Тху. Интегральная методика исследования организационной культуры. Науковедение. 2017. T. 7. № 1. URL: http://naukovedenie.ru/ PDF/115EVN 115.pdf. doi: 10.15862/115EVN115. 45. Ринкевич Н.С. Організаційна культура підприємств: виклики, загрози та тенденції. Економічний вісник Донбасу. 2019. № 3 (57). C. 123-136. doi: 10.12958/1817-3772-2019-3(57)123-136. 46. Трушкіна Н.В., Ринкевич Н.С. Цифрова трансформація організаційної культури підприємств: особливості, бар'єри та драйвери. Сучасні процеси трансформації у бізнесі та виробництві: теорія, методологія, практика (зовнішньоекономічна діяльність, промислове виробництво та транспорт): монографія / за ред. Л.М. Савчук, Л.М. Бандоріної; Нац. металургійна академія України. Дніпро: Пороги, 2019. С. 340350. 47. Трушкина Н.В., Рынкевич Н.С. Клиентоориентированность: основные подходы к определению. Бізнес Інформ. 2019. № 8. С. 244-252. doi: https: // doi.org/ 10.32983/2222-4459-2019-8-244-252. 48. Rynkevich N. Organizational-economic mechanism of management development of organizational culture of enterprises. Organizational-economic mechanism of management innovative development of economic entities: collective monograph / edited by M. Bezpartochnyi, in 3 Vol.; Higher School of Social and Economic. Przeworsk: WSSG, 2019. Vol. 3. Р. 119-128. 49. Діяльність суб'єктів господарювання за 2018 рік: стат. збірник. Київ: Державна служба статистик України, 2019. 154 с.

\section{References}

1. Khaiet H.L. (Ed.). (2003). Korporatyvna kultura [Corporate culture]. Kyiv, Center for Educational Literature [in Ukrainian].

2. Elnesson M. (2005). Organizational culture. Trans. from English. Kharkov, Publishing House of the Humanitarian Center [in Russian]. 
3. Sheyn E. (2007). Organizatsionnaya kul'tura i liderstvo [Organizational Culture and Leadership]. 3rd ed. Trans. from English. SPb., Piter [in Russian].

4. Moroz O.V., Karachyna N.P., Khalimon T.M. (2007), Korporatyvne upravlinnia na pidpryiemstvakh Ukrainy: postpryvatyzatsiinyi etap evoliutsii [Corporate governance at Ukrainian enterprises: post-privatization stage of evolution]. Vinnytsia. UNIVERSUM - Vinnytsia [in Ukrainian].

5. Armstrong M. (2009). Human Resource Management Practice. 10th ed. Trans. from English. SPb., Piter [in Russian].

6. Bala O.I., Mukan O.V., Bala R.D. (2010). Pryntsypy korporatyvnoi kultury pidpryiemstv: sutnist ta vydy [Principles of corporate corporate culture: nature and types]. Visnyk NU «Lvivska politekhnika»-Bulletin of NU "Lviv Polytechnic", Issue 682, pp. 11-15. Retrieved from http://ena.lp.edu.ua:8080/bitstream/ ntb/7852/1/02.pdf [in Ukrainian].

7. Zakharchyn H.M., Liubomudrova N.P., Vynnychuk R.O., Smolinska N.V. (2011). Korporatyvna kultura [Corporate culture]. Lviv, Lviv Polytechnic National University [in Ukrainian].

8. Tymtsunyk V.I., Haidai Yu.V. (2011). Rol orhanizatsiinoi kultury $\mathrm{v}$ diialnosti pidpryiemstv torhivli [The role of organizational culture in the activity of trade enterprises]. Derzhavne upravlinnia: udoskonalennia ta rozvytok - Public Administration: Improvement and Development, 3. Retrieved from http:www.dy.nayka. com.ua/ ?op $=1 \& \mathrm{z}=267$ [in Ukrainian].

9. Lahutina T. (2012). Orhanizatsiina kultura u problemnomu instytutsiinomu seredovyshchi [Organizational culture in a problematic institutional environment]. Visnyk KNTEU - KNTEU Bulletin, 3, pp. 123-131 [in Ukrainian].

10. Lifintsev D. (2014). Rol orhanizatsiinoi kultury u dovhostrokovomu rozvytku orhanizatsii [The role of organizational culture in long-term development of organizations]. Stratehiia ekonomichnoho rozvytku Ukrainy - Economic Development Strategy of Ukraine, 35, pp. 107-114 [in Ukrainian].

11. Karamushka L.M., Kredentser O.V., Tereshchenko K.V. et al. (2015). Psykholohichni determinanty rozvytku orhanizatsiinoi kultury [Psychological determinants of organizational culture development]. Kyiv, Pedahohichna dumka [in Ukrainian].

12. Ozirska N.V. (2015). Kontseptualni vidminnosti ta tochka peretynu orhanizatsiinoi ta korporatyvnoi kultury [Conceptual differences and the point of intersection of organizational and corporate culture]. Naukovyi visnyk Khersonskoho derzhavnoho universytetu. Ser.: Ekonomichni nauky. - Scientific Bulletin of Kherson State University. Ser.: Economic Sciences, Vol. 13, part 3, pp. 91-94 [in Ukrainian].

13. Doroshuk H.A. (2016). Upravlinnia orhanizatsiinym rozvytkom: teoretychni ta kontseptualni osnovy [Organizational Development Management: Theoretical and Conceptual Foundations]. Odesa, Bondarenko M.O. [in Ukrainian].

14. Kharun O.A., Stetsiuk O.V. (2017). Sutnisni kharakterystyky korporatyvnoi kultury pidpryiemstv [Essential characteristics of corporate culture of enterprises]. Ekonomika i suspilstvo - Economy and society, Issue 13, pp. 139-144 [in Ukrainian].
15. Androsova O.F. (2017). Istorychni aspekty vynyknennia poniattia «korporatyvna kultura»: sutnist, elementy, vlastyvosti, typy [Historical aspects of the emergence of the concept of "corporate culture": nature, elements, properties, types]. Intehratsiia osvity, nauky $i$ biznesu - Integration of education, science and business, Vol. 5, pp. 94-101. Zaporizhzhia, Zaporizhzhia_National University [in Ukrainian].

16. Fokina-Mezentseva K.V. (2018). Motyvatsiini osnovy korporatyvnoi kultury $\mathrm{v}$ systemi menedzhmentu yakosti pidpryiemstva: teoriia, metodolohiia, praktyka [Motivational foundations of corporate culture in th e enterprise quality management system: theory, methodology, practice]. Kherson, Helvetika Publishing House [in Ukrainian].

17. Otenko I.P., Chepeliuk M.I. (2018). Korporatyvna kultura: mizhnarodnyi ta transformatsiinyi aspekty [Corporate culture: international and transformational aspects]. Kharkiv, KhNEU im. S. Kuznetsia [in Ukrainian].

18. Kirkhler E., Shrot A. (2004). Prinyatiye resheniy v organizatsiyakh. Psikhologiya truda i organizatsionnaya psikhologiya. Per. s nem. Khar'kov, Izd-vo Gumanitarnyy Tsentr [in Russian].

19. Kuznetsova S.A., Kuznetsov A.A. (2011). Formuvannia korporatyvnoi kultury v zalezhnosti vid spetsyfiky pidpryiemstva [Formation of corporate culture depending on the specifics of the enterprise]. Problemy ekonomiky - Problems of economy, 4, pp. 91-94 [in Ukrainian].

20. Didenko N.V. (2012). Formuvannia mekhanizmu orhanizatsiinoi kultury [Formation of the mechanism of organizational culture]. Biznes Inform - Business Inform, 6, pp. 206-207 [in Ukrainian].

21. Kuznetsov A.A. (2013). Pryntsypy upravlinnia korporatyvnoiu kulturoiu pidpryiemstva $\mathrm{V}$ nestabilnii ekonomitsi [Principles of corporate culture management in an unstable economy]. Biznes Inform - Business Inform, 7, pp. 352-356 [in Ukrainian].

22. Volianska-Savchuk L.V. (2014). Transformatsiia korporatyvnoi kultury mashynobudivnykh pidpryiemstv [Transformation of corporate culture of machine-building enterprises]. Ekonomika: realii chasu-Economy: the realities of time, 6(16), pp. 50-56 [in Ukrainian].

23. Potorochyn S.O. (2014). Upravlinnia orhanizatsiinoiu kulturoiu na promyslovykh pidpryiemstvakh [Management of organizational culture at industrial enterprises]. Ekonomika: realii chasu - Economy: the realities of time, 3 (13), pp. 57-63 [in Ukrainian].

24. Derhachova V.V., Fedirko H.A. (2018). Osoblyvosti formuvannia korporatyvnoi kultury na pidpryiemstvakh Ukrainy [Features of formation of corporate culture at the enterprises of Ukraine]. Ekonomichnyi visnyk NTUU «KPI»-Economic Bulletin of NTUU "KPI", 15, pp. 1-8. doi: https://doi.org/10.20535/2307-5651.15.2018.135694 [in Ukrainian].

25. Telishevska L.I., Uspalenko V.I. (2019). Tendentsii rozvytku systemy upravlinnia personalom na pidpryiemstvi [The trends in the development of the hr management system at the enterprise]. Ekonomichnyi visnyk Donbasu - Economic Herald of the Donbas, 2(56), pp. 187-197. doi: 10.12958/1817-3772-2019-2(56)-187197 [in Ukrainian]. 
26. Denison D.R.(1984). Bringing corporate culture to the bottom line. Organizational Dynamics, Vol. 13 (2), pp. 4-22.

27. Irani Z., Beskase A., Love P.E.D. (2004). Total quality management and corporate culture: constructs of organizational excellence. The International Journal of Technological Innovation, Entrepreneurship and Technology Management - Technovation, Vol. 24, pp. 643-650.

28. Kwan P., Walker A. (2004). Validating the competing values model as a representation of organizational culture through inter-institutional comparisons. Organizational Analysis, Vol. 12, No 1, pp. 21-37.

29. Millington M.J., Schultz J.C. (2009). The Challenge of Organization Culture in Quality Assurance Implementation. Journal of Rehabilitation Administration, Vol. 33, pp. 121-130.

30. Kharchyshyna O.V. (2010). Orhanizatsiina kultura: teoretychni zasady ta vzaiemozviazok iz konkurentospromozhnistiu pidpryiemstva [Organizational culture: Theoretical background and the relationship with enterprise competitiveness]. Zabezpechennia sotsialnoekonomichnoho rozvytku hospodariuiuchykh system $v$ umovakh tranzytyvnoi ekonomiky - Providing socio-economic development of economic systems in a transitive economy. Zhytomyr: Vyd-vo ZhDTU, pp. 182-202 [in Ukrainian].

31. Cameron K.S., Quinn R.E. (2011). Diagnosing and Changing Organizational Culture: Based on the Competing Values Framework. 3rd ed. New Jersey: John Wiley \& Sons. 288 p.

32. Roldan J.L., Leal-Rodríguez A.L., Leal A.G. (2012). The influence of organizational culture on the Total Quality Management Programme performance. Investigaciones Europeas de Dirección y Economía de la Empresa, Vol. 18, pp. 183-189.

33. Kravchenko V.O., Nykyforenko V.H. (2012). Otsinka vplyvu orhanizatsiinoi kultury na efektyvnist ta konkurentospromozhnist pidpryiemstva [Assessment of the influence of organizational culture on the efficiency and competitiveness of the enterprise]. Biznes Inform Business Inform, 10, pp. 260-263 [in Ukrainian].

34. Znak K.O. (2012). Porivnialnyi analiz metodychnykh pidkhodiv do diahnostuvannia korporatyvnoi kultury ta perspektyvy yikh vykorystannia na pidpryiemstvakh mashynobudivnoi haluzi [Comparative analysis of methodological approaches to the diagnosis of corporate culture and prospects of their use in the enterprises of the machinebuilding industry]. Biznes Inform - Business Inform, 11, pp. 270-272 [in Ukrainian].

35. Ovcharenko M.I., Cherviakova S.V. (2013). Metodychne zabezpechennia otsinky stanu korporatyvnoi kultury pidpryiemstva [Methodological support for the assessment of the corporate culture of the enterprise]. Marketynh i menedzhment innovatsii - Marketing and innovation management, 2, pp. 130-141 [in Ukrainian].

36. Lapina I., Kairisa I., Aramina D. (2015). Role of Organizational Culture in the Quality Management of University. 20th International Scientific Conference Economic and Management - 2015 (ICEM - 2015). Procedia - Social and Behavioral Sciences, Vol. 213, pp. 770-774. doi: 10.1016/j.sbspro.2015.11.472.

37. Zhezher K.L. (2015). Osnovni pidkhody ta metodyky diahnostyky korporatyvnoi kultury suchasnoho pidpryiemstva [Basic approaches and methods of diagnostics of corporate culture of modern enterprise]. Molodyi vchenyi - Young scientist, 11(26), pp. 61-64 [in Ukrainian].

38. Denison D.R. (1990). Corporate culture and organizational effectiveness. New York: John Wiley \& Sons. 267 p.

39. Hofstede G. (2011). Dimensionalizing Cultures: The Hofstede Model in Context. Online Readingsin Psycology and Culture, Vol. 2 (1), pp. 1-7.

40. Denison D., Khoyshberg R., Leyn N., Lif K. (2013). Izmeneniye korporativnoy kul'tury $\mathrm{V}$ organizatsiyakh [Change in corporate culture in organizations]. $\mathrm{SPb}$., Piter [in Russian].

41. Zerkal A.V. (2012). Modeliuvannia rozvytku korporatyvnoi kultury na mashynobudivnykh pidpryiemstvakh [Modeling of development of corporate culture at machine-building enterprises]. Efektyvna ekonomika - Efficient economy, 9. Retrieved from http:www.economy. nayka.com.ua/?op=1\&z=13892012 [in Ukrainian].

42. Kuznetsov A.A. (2013). Modeliuvannia polikryterialnoi otsinky stanu upravlinnia korporatyvnoiu kulturoiu mashynobudivnykh pidpryiemstv [Modeling of multicriteria assessment of the corporate culture management status of machine-building enterprises]. Investytsii: praktyka ta dosvid - Investment: practice and experience, 19, pp. 88-91 [in Ukrainian].

43. Voinarenko M.P., Volianska-Savchuk L.V. (2016). Zastosuvannia ekspertnykh metodiv doslidzhennia dlia otsinky rivnia korporatyvnoi kultury na pidpryiemstvakh mashynobuduvannia [Application of expert research methods to assess the level of corporate culture in engineering enterprises]. Visnyk Khmelnytskoho natsionalnoho universytetu. Ser.: Ekonomichni nauky - Bulletin of Khmelnitsky National University. Ser .. Economic Sciences, 5, Vol. 1, pp. 298-300 [in Ukrainian].

44. To Thu Trang. (2017). Integral'naya metodika issledovaniya organizatsionnoy kul'tury [The integrated methodology of organizational culture investigation]. Naukovedenie, Vol. 7, No. 1. Retrieved from http: //naukovedenie.ru/PDF/115EVN115.pdf. doi: 0.15862/115EVN 115 [in Russian].

45. Rynkevich N. S. Orhanizatsiina kultura pidpryiemstv: vyklyky, zahrozy ta tendentsii [Organizational culture of enterprises: challenges, threats and trends]. Ekonomichnyi visnyk Donbasu - Economic Herald of the Donbas, 3(57), pp. 123-136. doi: 10.12958/1817-37722019-3(57)-123-136 [in Ukrainian].

46. Trushkina N.V., Rynkevych N.S. (2019). Tsyfrova transformatsiia orhanizatsiinoi kultury pidpryiemstv: osoblyvosti, bariery ta draivery. Suchasni protsesy transformatsii $\mathrm{u}$ biznesi ta vyrobnytstvi: teoriia, metodolohiia, praktyka (zovnishnoekonomichna diialnist, promyslove vyrobnytstvo ta transport) [The digital transformation of corporate organizational culture: features, barriers and drivers. Modern processes of transformation in business and production: theory, methodology, practice (foreign economic activity, industrial production and transport)] (pp. 340-350). Dnipro, Porohy [in Ukrainian].

47. Trushkina N.V., Rynkevich N.S. (2019). Kliyentooriyentirovannost': osnovnyye podkhody $\mathrm{k}$ opredeleniyu [Customer focus: basic approaches to definition]. Business Inform, 8, pp. 244-252. doi: https://doi.org/ 10.32983/2222-4459-2019-8-244-252 [in Russian]. 
48. Rynkevich N. (2019). Organizational-economic mechanism of management development of organizational culture of enterprises. Organizational-economic mechanism of management innovative development of economic entities: collective monograph in 3 Vol.; Higher School of Social and Economic. Przeworsk:, WSSG, Vol. 3 pp. 119128.

49. Diial'nist' sub'iektiv hospodariuvannia za 2018 rik: stat. zb. [Activity of Business Entities 2018: statistical publication]. (2019). Kyiv, State Statistics Service of Ukraine. 154 p. [in Ukrainian].

Ринкевич Н. С. Емпіричне дослідження особливостей розвитку організаційної культури будівельних підприємств

На даний час актуалізуються проблеми розвитку організаційної культури підприємств різних видів економічної діяльності з урахуванням їх специфіки. Це дозволяє досягти більшої гнучкості й здатності оперативно реагувати на зміни внутрішнього і зовнішнього середовища, посилити конкурентні позиції на ринках збуту, що відповідає сучасним умовам господарювання.

Мета даного дослідження полягає в емпіричному дослідженні особливостей організаційної культури будівельних підприємств, виявленні тенденцій іiі розвитку в сучасних умовах та удосконаленні методичного підходу до оцінювання рівня розвитку.

У результаті дослідження проаналізовано динаміку кількості зайнятих і найманих працівників у сфері будівництва. Викладено результати проведеного експертного опитування з метою виявлення сучасних проблем, бар'єрів, особливостей, тенденцій та шляхів розвитку організаційної культури будівельних підприємств в Україні. Виконано оцінку рівня розвитку організаційної культури підприємств. Запропоновано інтегральну методику оцінки організаційної культури будівельних підприємств. Апробація даної методики показала, що обстежені підприємства мають середній рівень розвитку організаційної культури $(0,69)$, оскільки значення інтегрального показника знаходиться в межах $0,5-0,75$.

Ключові слова: будівельне підприємство, організаційна культура, управління розвитком організаційної культури, експертне опитування, методики оцінки, тенденції, ефективність.

Rynkevich N. Empirical Research of Development Features of the Organizational Culture of Construction Enterprises

Currently, the problems of developing the organizational culture of enterprises of various types of economic activity are being updated taking into account their specifics. This allows you to achieve greater flexibility and the ability to quickly respond to changes in the internal and external environment, to strengthen competitive positions in the sales markets, which corresponds to modern business conditions.
The purpose of this study is an empirical research of the organizational culture of construction enterprises, identifying trends in its development in modern conditions and improving the methodological approach to assessing the level of development.

As a result of the research, the dynamics of the number of employed and hired workers in the construction industry is analyzed. The results of an expert survey are presented to identify current problems, barriers, features, trends and ways of developing the organizational culture of construction enterprises in Ukraine. An assessment of the level of development of the organizational culture of enterprises. An integrated methodology for assessing the organizational culture of construction enterprises is proposed. Testing of this methodology showed that the surveyed enterprises have an average level of organizational culture development (0.69), since the value of the integral indicator is in the range of $0.5-0.75$.

Keywords: construction enterprise, organizational culture, organizational culture development management, expert survey, assessment methods, trends, efficiency.

Рынкевич Н. С. Эмпирическое исследование особенностей развития организационной культуры строительных предприятий

В настоящее время актуализируются проблемы развития организационной культуры предприятий различных видов экономической деятельности с учетом их специфики. Это позволяет достичь большей гибкости и способности оперативно реагировать на изменения внутренней и внешней среды, усилить конкурентные позиции на рынках сбыта, что соответствует современным условиям хозяйствования.

Цель данного исследования заключается в эмпирическом исследовании особенностей организационной культуры строительных предприятий, выявлении тенденций ее развития в современных условиях и совершенствовании методического подхода к оценке уровня развития.

В результате исследования проанализирована динамика количества занятых и наемных работников в сфере строительства. Изложены результаты проведенного экспертного опроса с целью выявления современных проблем, барьеров, особенностей, тенденций и путей развития организационной культуры строительных предприятий в Украине. Выполнена оценка уровня развития организационной культуры предприятий. Предложена интегральная методика оценки организационной культуры строительных предприятий. Апробация данной методики показала, что обследованные предприятия имеют средний уровень развития организационной культуры $(0,69)$, поскольку значение интегрального показателя находится в пределах 0,50,75 .

Ключевые слова: строительное предприятие, организационная культура, управление развитием организационной культуры, экспертный опрос, методики оценки, тенденции, эффективность.

Received by the editors: 09.12.2019 and final form 19.12.2019 